\title{
Emotional labor in nursing praxis
}

\author{
O trabalho emocional na práxis de enfermagem
}

Trabajo en praxis emocional de enfermería

José Manuel da Silva Vilelas ${ }^{\mathrm{a}}$
Paula Manuela Jorge Diogo

DOl: $\quad$ http://dx.doi.org/10.1590/19831447.2014.03.45784

\section{ABSTRACT}

Healthcare work is, by nature, an activity full of intense emotions and therefore, is opportune ground for exploring emotions in the workplace in different contexts of nursing care. It is a very fertile terrain if care is focused on the emotions of the client, nurses, healthcare teams, and on the interaction of all actors involved. This article presents a theoretical reflection exploring the concept of emotional labor in the context of nursing care. Theoretical references from several fields of knowledge, namely sociology and nursing, have been adopted to conceptualize the theme. Studies on emotional labor have contributed toward the understanding of the key issue of emotional management in healthcare institutions and both its positive and negative impact on clients and professionals. The development of the theme of emotional labor in nursing has given rise to numerous theoretical approaches and perspectives explaining this concept.

Descriptors: Labor. Emotions. Emotional intelligence. Nursing care.

\section{RESUMO}

Trabalho em saúde é, por sua natureza, uma atividade de emoções intensas e, assim, é um terreno propício para a exploração das emoções no local de trabalho e em diferentes contextos de cuidados de enfermagem. Trata-se de um terreno muito fértil, se a atenção se focar nas emoções do cliente, dos enfermeiros, das equipas, nas interações dos atores envolvidos. Este artigo de carater teórico-reflexivo pretende explorar o conceito de trabalho emocional no contexto de cuidados de enfermagem. Adotaram-se referenciais teóricos de diversas áreas do conhecimento, nomeadamente sociologia e enfermagem, para explicitarem a concetualização da temática. Estudos sobre o trabalho emocional têm contribuído para 0 entendimento da crucial gestão de emoções nas instituições de saúde, bem como do impacto tanto positivo como negativo sobre clientes e profissionais. 0 desenvolvimento da concepção de trabalho emocional em enfermagem tem gerado e mobilizado inúmeras abordagens teóricas e perspetivas para explicar este conceito. Descritores: Trabalho. Emoç̃oes. Inteligência emocional. Cuidados de enfermagem.

\section{RESUMEN}

La acción sanitaria es, por su naturaleza, una actividad de intensas emociones y por lo tanto es adecuada para la exploración de las emociones en el terreno laboral y en diferentes contextos de atención de enfermería. Un terreno muy fértil para centrar la atención en las emociones del cliente, las enfermeras, los equipos, las interacciones de los actores involucrados. Este artículo de carácter teórico y reflexivo explorará el concepto de trabajo emocional en el contexto de la atención de enfermería. Se adoptaron marcos teóricos fundamentados en diversas áreas del conocimiento, incluyendo la sociología y de enfermería, que explican la conceptualización de estudios temáticos sobre el trabajo emocional, han contribuido a la comprensión de la gestión de claves en instituciones de salud emocionales, tanto positivas como impactos negativos como acerca de los clientes y profesionales. El desarrollo del diseño del trabajo emocional en enfermería se ha generado y ha movilizado numerosos enfoques teóricos y perspectivas para explicar este concepto. Descriptores: Trabajo. Emociones. Inteligencia emocional. Atención de enfermería. 


\section{口INTRODUCTION}

Emotions are ubiquitous among humans. Without emotions, there would be no action. Every organization is a space where emotions shape relationships and environments. Emotions are, in fact, a comprehensive part of daily adjustment to work, and professionals must be able to recognize and manage their own emotional states, as well as those of others. ${ }^{(1)}$ Caring is a relational process, a means of communicating and expressing human emotion.(2) Nursing is a demanding occupation, for the professional must provide the client/family with a helping relationship of great emotional involvement, for the object of nursing is the human being with all its strength and vulnerability. ${ }^{(3)}$ Caring cannot be done in isolation, but must take into account a set of social, cultural and economic dimensions for each population and each form of care. ${ }^{(4)}$ Thus, there is nursing knowledge and nursing praxis, which is the practice side of the profession. Knowledge allows for practice in the sense of action through competencies, which leads to awareness in practice. By using the knowledge that has been constructed, deconstructed and reconstructed daily via the process of reflection-action, a specific type of nursing praxis is created, centered on the needs of the human being and built on scientific evidence. Caring requires an interaction between people, and all interaction is permeated by emotions and feelings. ${ }^{(5)}$ Thus, the present study seeks to explore the concept of emotional labor in the context of nursing care.

\section{- EMOTIONAL LABOR AND THEORETICAL PERSPECTIVES}

The concept of emotional labor first emerged in sociology. Organizations determine that the expression of emotions be in accordance to rules of emotional display that reflect certain standards in terms of the professionals' behavior during their interactions with clients. ${ }^{(6)}$ In order to abide by these rules, professionals must control their emotions. This control can be achieved in one of two ways: "surface acting" and "deep acting."The first refers to the manip- ulation of emotional expression without modification of inner feelings, whereas in the latter, individuals consciously modify inner feelings in order to display appropriate emotions. Although deep acting is a more authentic form of emotional control, both processes require effort and imply emotional dissonance, which leads to situations of repeated stress, isolation and exhaustion. ${ }^{(6)}$ The first model of emotional labor ${ }^{(6)}$ was represented through a process in which professionals are driven and directed by the employer. Even though they can sometimes go against what is expected, in general, they are conditioned by the power of the organization. The main goal is to increase profits through client satisfaction. (Figure 1).

This pioneer conceptualization was a reliable, original and propelling basis from which other studies on emotional labor emerged.

Other authors ${ }^{(7)}$ underscore that the rules for display imposed by emotional labor are related to the emotional expectations of the organization and of others, as opposed to the previous model ${ }_{1}^{(6)}$ which focused primarily on feelings (a position adopted by most authors and by current research). This model defends that emotional labor can result in positive outcomes..$^{(7)}$ As an example, there is the case of the nurse who is naturally empathic with sick children, which leads to the display of necessary and appropriate emotions for the role. This means that nurses did not "labor" to build particular emotions, in order to be in accordance to what is expected as a professional. Emotional labor depends on nurses' capacity to adjust their identity to their role and to be in accordance with the rules of the organization. Emotional autonomy allows for a closer connection with clients in individuals interactions, leading to greater professional satisfaction and consequently, well-being. (Figure 2).

Other authors ${ }^{(8)}$ explain emotional labor using a fourstep model to display how individuals constantly monitor, compare and modify their behavior in order to comply with determined goals. Individuals have self-perception of their emotional display, compare the actual display to the rules for display, act to reduce any discrepancy (modifying behavior to coincide with a rule, or if this is challenging,

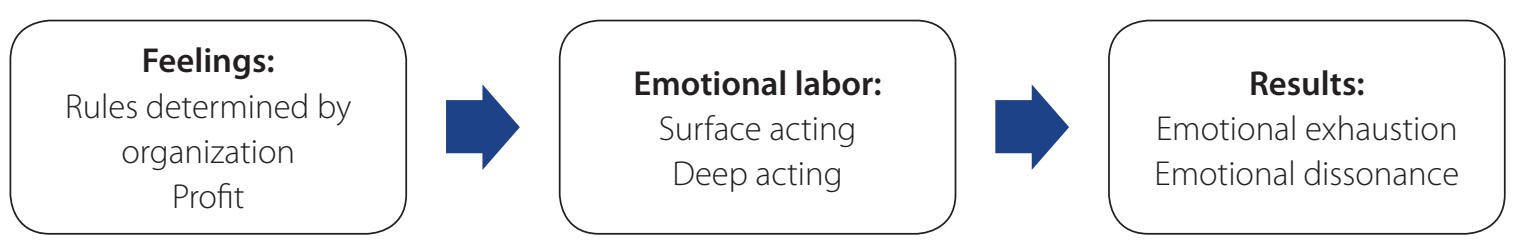

Figure 1 - Adapted from the Hochschild Model of Emotional Labor ${ }^{(6)}$. 
abandoning the display rule as a standard for behavior), and display a situation-appropriate emotion. Discrepancy between what is necessary and what is truly felt generates emotional effort, as well as organizational and personal costs. This effort can possibly lead to burnout. ${ }^{(8)}$ Furthermore, if the professional is incapable of abiding by the rules and opts for a modified standard of emotional expression, feelings of inadequacy and low satisfaction with work can arise. ${ }^{(8)}$ (Figure 3).

These models suggest that emotional labor needs to be studied in more depth, so as to be incorporated by health policies and practices. Exploring the potential of emotions in nursing is only possible through education and training, being informed about the results of studies on emotional labor and by developing a practice based on the best evidence.

\section{EMOTIONAL LABOR IN NURSING}

Emotional labor is a significant component of occupations that require interaction with clients. The specific requisites for interaction among healthcare professionals demand a specific model of emotional labor. ${ }^{(9-10)}$ In fact, the pioneer and original concept, which associated emo- tional labor with stress and emotional dissonance has been broadened, in the current field of nursing, to include three other perspectives. Together they attempt to explain emotional labor. Taking into account all four perspectives (as a result of the process of caring, as a nursing competence, as self-regulation of nurses' emotions, and as stressful work), different explanatory processes and models emerge based on nursing practice.

The concept of emotional labor has expanded in light of nursing referential systems and practice. ${ }^{(11)}$ It can be defined as "face-to-face or voice-to-voice contact," which produces an emotional state in another person. In order to be controlled, training and clinical supervision is required. Emotional labor implies mobilizing competencies that frequently go unseen, such as providing support and tranquility, courtesy, friendliness, a sense of humor, patience, relieving suffering, and knowing clients and helping to solve their problems. Thus, nurses manage the emotions of the client, the suffering inherent to the health-illness process, as well as their own emotional experience of caring.

In general, emotions are expressed in order to influence the attitudes and behavior of others, to influence people's expression of emotion. ${ }^{(12)}$ A nurse can speak in a gentle and calming manner in order to soothe a very anxious client,

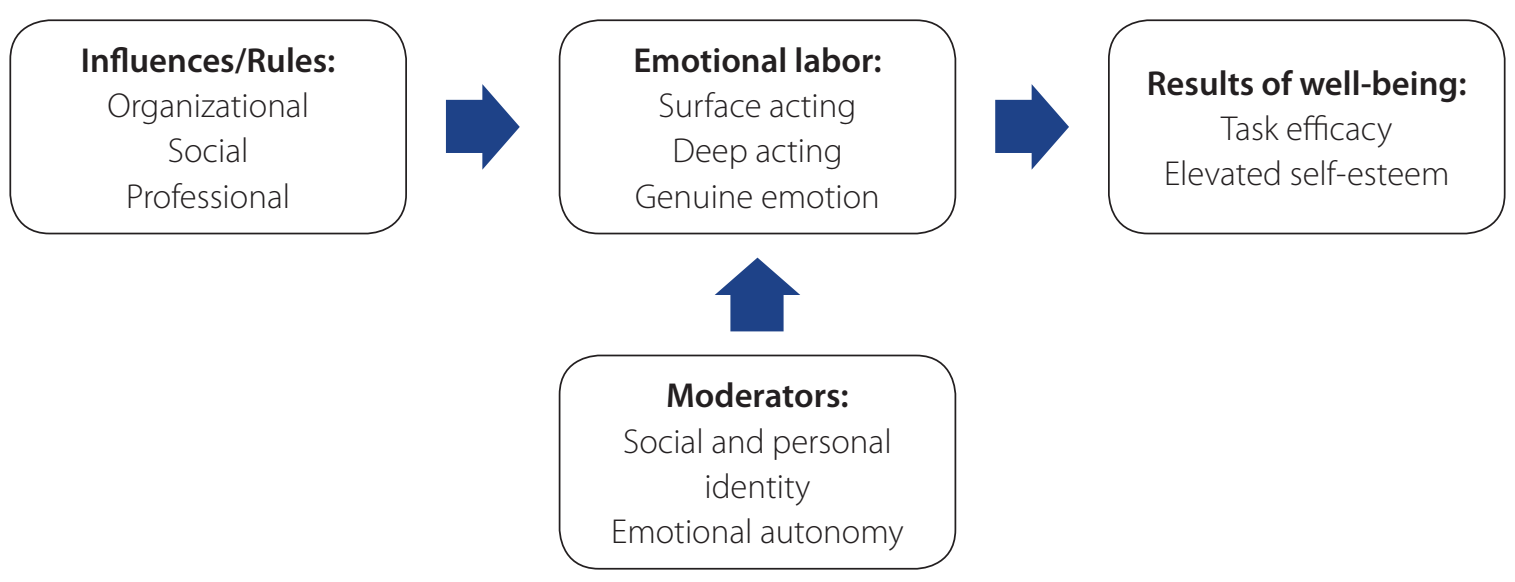

Figure 2 - Adapted from the Ashforth and Humphrey Model of Emotional Labor(7).

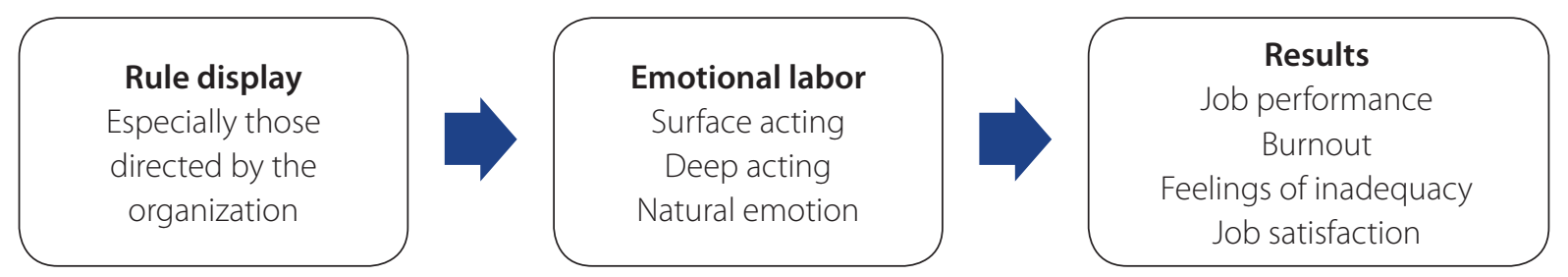

Figure 3 - Adapted from the Diefendorff and Gosserand Model of Emotional Labor ${ }^{(8)}$. 
or can be assertive with a diabetic client who is not able to control an eating compulsion. Therefore, emotional labor has to be present in order to modify the emotions attitudes and behavior of clients toward a desired direction, ${ }^{(12)}$ in terms of their health.

The concept of emotional labor in nursing has evolved to include the well-being of professionals and its therapeutic results, ${ }^{(9,12)}$ focusing mainly on the nurse-client relationship. Nurses want to provide authentic care, for they feel it is part of their expected professional role, be it at an organizational level, at the level of the profession's social representations, or even due to the demands of professionals on their own selves. ${ }^{(9)}$

One study ${ }^{(13)}$ demonstrates the process of using emotions therapeutically in pediatric nursing. In this model, nurses seek to manage in their daily practice the emotions of their clients when faced with illness and hospitalization, for these experiences have the potential for being distressing and weakening children/families. The strategies used are specific and appropriate to the concrete situation, producing therapeutic results. They transform distressing emotional phenomena for the clients as well for the nurses. It is a process that allows for distressing emotional phenomena (for client and nurse) to be transformed into restorative and adaptive emotional states. In other words, states that promote well-being and aid the client in adapting to the situation. Nurses use the client's and their own emotionality intentionally to positively influence the experience of illness and hospitalization, relationships and care provided, bringing relief to suffering and heightening well-being, all factors which result in the growth of both parties. Therapeutic intentionality means helping to modify distressing emotional states experienced by clients into states of greater tranquility, as well as helping clients obtain greater control over the situation and their global well-being (Figure 4).
Thus, emotional labor in the healthcare context involves assessing emotional regulation strategies available to healthcare professionals. This includes analyzing how nurses manage their own emotions and that of others through their interactions. Nurses need to deal explicitly with the uncomfortable and sometimes conflicting emotions that nurses, health professionals, clients and families have to face. In order to manage difficult events and problems in clinical practice, personal development and a reflective nursing practice are essential. ${ }^{(13)}$

\section{口 FINAL CONSIDERATIONS}

Nursing studies tend to focus on aspects which can be evaluated, measured, and that possess almost immediate effects on the results sensitive to nursing care. In other words, they adopt aspects whose effectiveness can be analyzed through the cost-benefit relation, such as the acquisition of technical competencies. Science is understood as a purely rational and objective business, and it has a hard time admitting irrational and subjective components of human emotion. ${ }^{(14)}$ Applying the concept of emotional labor to nursing requires learning how to manage emotion and emotional competencies. Emotional labor requires an individualized but trained response, which helps manage the emotions of the people in the daily work routine of healthcare organizations. Nursing is the prototype of caring professions, and the nurse-client relationship demands emotional labor. Caring is at the essence of the profession. In fact, caring was formalized through nursing theories, especially Watson's theory of human caring. ${ }^{(15)}$ In conclusion, the authors believe they have provided a clear idea of the state of the art concept of emotional labor and a conceptualization that includes how professionals express and restrict their emotions as a functional aspect of their

\begin{tabular}{|c|c|c|}
\hline $\begin{array}{l}\text { Antecedents: } \\
\text { 1. Distressing emotional } \\
\text { experience/emotional } \\
\text { suffering (clients) } \\
\text { 2. Affective needs and } \\
\text { exposure to stress factors } \\
\text { (clients) } \\
\text { 3. Emotional impact/ } \\
\text { absorbing suffering } \\
\text { (nurses) }\end{array}$ & $\begin{array}{l}\text { Strategies/instruments: } \\
\text { 1. Promoting a safe and } \\
\text { caring environment } \\
\text { 2. Nurturing needs whit affection } \\
\text { 3. Managing client's emotions } \\
\text { 4. Constructing a stable } \\
\text { relationship } \\
\text { 5. Regulating emotional } \\
\text { willingness for caring (nurse) }\end{array}$ & $\begin{array}{l}\text { Consequences: } \\
\text { 1. Emotional experience } \\
\text { positively transformed } \\
\text { 2. Heightened well-being/ } \\
\text { relief of suffering } \\
\text { 3. Personal growth } \\
\text { 4. Adaptation to health } \\
\text { illness process }\end{array}$ \\
\hline
\end{tabular}

Figure 4 - Adapted from the Diogo Model of Emotional Labor in Pediatric Nursing(13). 
roles. However, the widespread and relevant applicability of emotional labor theories for several professions, including health care, suggests that this discussion still needs to be further researched and tested.

\section{REFERENCES}

1. Hunter A, Smith R. Emotional labour: just another buzz word? Int J Nurs Stud.2007;44(6): 859-61.

2. Watson J. Can an ethic of caring be maintained? J Adv Nurs.2006;54(3):257-9.

3. Vilelas JM.0 trabalho emocional no ato de cuidar em enfermagem: uma revisão do conceito. Rev Ciências Saúde ESSCVP-Salutis Scientia. 2013;5:41-50.

4. Collière M. Cuidar. . . a primeira arte da vida. Loures: Lusociência; 2003.

5. Goleman D. Inteligência emocional. Lisboa: Temas e debates; 2003.

6. Hochschild AR. The Managed heart: commercialization of human feeling. Berkeley: University of California Press; 1983.

7. Ashforth BE, Humphrey RH. Emotional labor in service roles: the influence of identity. Acad Manage Rev.1993; 18(1):88-115.
8. Diefendorff JM, Gosserand RH. Understanding the emotional labor process: a control theory perspective. J. Organ. Behav.2003;24(8):945-59.

9. De Raeve $L$. The modification of emotional responses: A problem for trust in nurse-patient relationships? Nurse Ethics.2002; 9(5):465-71.

10. Mann S. A health-care model of emotional labour: an evaluation of the literature and development of a model. J Health Organ Manag.2005; 19(4):304-17.

11. Smith P. The emotional labour of nursing revisited: can nurses still care? Hampshire: Palgrave Macmillan; 2011.

12. Zapf D. Emotion work and psychological wellbeing: A review of the literature and some conceptual considerations. Hum Resour Manage $R$. 2002; 12:237-68

13. Diogo P. Trabalho com as emoções em enfermagem pediátrica: um processo de metamorfose da experiência emocional no acto de cuidar. Lisboa: Lusociência; 2012.

14. Gray B. The emotional labour of nursing: defining and managing emotions in nursing work. Nurse Educ Today.2009;29(2):168-75.

15. Fawcett J. Nursing qua nursing: the connection between nursing knowledge and nursing shortage. J Adv Nurs.2007:59(1):97-9.

\section{Author's address:}

José Manuel da Silva Vilelas

Casas de Azeitão

Rua dos Amores, lote 42

2925-010, Azeitão, Portugal

E-mail: jose.vilelas@gmail.com
Received: 19.03.2014

Approved: 26.06.2014 